\title{
Reflection of the Time Model Through German Derivational Structures
}

\section{Larisa Vladimirovna VORONINA ${ }^{1}$ (i)}

${ }^{1}$ Assoc. Prof., Belgorod National Research University, Faculty of Foreign Languages, Department of the German and French Languages, Belgorod, Russia

\section{ORCID: L.V.V. 0000-0002-9502-9505}

\section{Corresponding author:}

Larisa Vladimirovna VORONINA Belgorod National Research University, Faculty of Foreign Languages, Department of the German and French Languages, 14 Studencheskaya Street, 308007, Belgorod, Russia

E-mail: voronina@bsu.edu.ru

Submitted: 21.06 .2019

Accepted: 18.09.2019

Citation: Voronina, L. V. (2019). Reflection of the time model through German derivational structures. Litera, 29(2), 301-312. https://doi.org/10.26650/LITERA2019-0027

\section{ABSTRACT}

The research paper aims to show the potential of word-formation models of the German language representing the interrelation between the two most significant constituents of the picture of the world - the concepts of the LIVING BEING and TIME. The analysis is carried out on the material of substantive composite words, i.e. verbal representatives of the propositional structure AKTOR - SITUATION/PRÄDIKAT (SITUATION) - ZEIT/ACTOR - SITUATION/PREDICATE (SITUATION) - TIME, coupled with the models of the German language $N+N, N+N(v), A+N$. Nouns generated on the basis of a given mental structure is supposed to model the idea of activities and the life cycle of wild life objects, as well as of abstract and inanimate entities to which a person attributes anthropomorphic properties.

A special substance, the activity of which is correlated with a specific fragment, a segment in the cyclic time model is stated to be cognitively distinguished in the conceptual structure of such a name. The paper under study particularly emphasises the fact that natural phenomena, flora and fauna species receive temporary characteristics taking into account their natural cycles, whereas acyclic situations that break stereotypical ideas about the time of human activity/passivity are considered part of the nomination sphere of a man's activities.

In the process of modelling knowledge about the existence of all things in the world, a great number of temporal nominees in the class of modern German nouns linked to this propositional structure is proved to indicate the informative and communicative significance of such language units.

Keywords: concept of TIME, cyclic time model, temporal nominators in the class of German nouns, compound word, propositional structure 


\section{Introduction}

The concept of TIME relates to the basic structures of human consciousness and is particularly relevant for human existence, for a person's idea of the world order. The being of the world and all living things are perceived through the prism of time.

Time is an abstract phenomenon that has a complex conceptual structure. The understanding of this category is carried out by such sciences as philosophy, physics, geology, mathematics, astronomy, biology, psychology, etc.

The formation of the concept of time as a physical quantity was particularly influenced by I. Newton's works. The scientist differentiated two types of time: absolute and relative. Absolute, true, mathematical time, in its essence, flows at a steady pace, without any relation to anything external. Relative, apparent, ordinary time is an exact or changeable measure of duration, comprehended by feelings, and used in everyday life instead of absolute time.

Despite the fact that the emergence of the theory of relativity disproved previous ideas about the independence of the flow of time from external factors, and proved the influence of body weight on the march of time, I. Newton's concept, in many respects, determined modern man's common notion of the phenomenon of time.

\section{Literature Review and Research Methods}

According to the contemporary scientific concepts, there are two basic models of time: the cyclical time model and the linear time model. The notion of the cyclical nature of time is associated with mythological consciousness. The world process in the latter looked like a series of repeated acts. "The regularity of the circular motion of the sun in the 'celestial sphere', the cyclical nature of the process itself, repeated again and again and not subject to any visible changes, served as the natural basis for choosing the solar cycle as the measure of the being of all things in the world" (Kravchenko, 2004, p. 76-77). In other words, the concept of the cyclical nature of time is associated with the perception of natural cycles: the changing of seasons, the time of day and recurring events in human life. Following the second model, time as a measure of movement and change is linear, unidirectional and irreversible. Every moment of time is unique and inimitable. 
The notion of time and the certain signs attributed to it are closely related to the person. In linguistics and philosophy, the role of the human factor in time modelling was repeatedly emphasised "because it is the man who is at the point of presence which conditionally divides the time line into its components" (Arutyunova, 1999, p. 689).

The feeling of time is interlinked with a person's mental structures. In this way, I. Kant considered time an intrinsic property of a person. The philosopher believed that space, time and forms of reason are the cognitive subject's inborn features and attitudes to reality, which are not, however, supposed to be deductible from reality itself. Space and time are not forms of the being of things that exist independently of our consciousness, on the contrary, they are subjective forms of human sensuality, originally inherent in a man as the representative of humanity.

Time is an intangible, elusive, ephemeral entity. A human does not have a special organ for the perception of time, but one has a sense of time generated by the perception of changes in the world. "If the sense of time is based on the perception of natural cycles, then the psychic structures are associated with linear time, dissected by the 'point of presence' into the past, future and present, connecting them into a single stream" (Arutyunova, 1999, p. 688). The perception of time is subjective and depends on many factors: age, physical and emotional state, etc. Along with some other abstract categories such as structure, measure, assessment, etc., time, at its core, is a mental construct created by a man.

The results of a man's comprehension of time are reflected in the language time model. In order to understand the characteristics of the concept of TIME in the German language picture of the world, it is necessary to turn to the analysis of vocabulary definitions of the lexeme Zeit (Eng. Time, see Duden, 1996, pp. 17701771; Sprach-Brockhaus, 1984, p. 804). The conceptual analysis conducted allows us to conclude that time in the linguistic consciousness is associated with the signs linked to both the cyclical and linear time models. The perception of time cyclicality is connected with such conceptual characteristics as 'cyclicality', 'periodicity', 'duration', 'intended use'; 'countability'. The linear model is reflected by some other characteristics of the TIME concept: 'one-pointedness', 'synchroneity', 'linearity', 'consistency of the past, present, future,' 'irreversibility', 'frailty of life, of the earthly world'. Among other things, the presence of the term Tempus in German considers a distinction in the languages of grammatical and experienced time. 


\section{Results and Discussion}

The ZEIT concept reveals a close connection with the concepts of LEBEWESEN/ LIVING BEING and NATUR/NATURE. As we see it, it is verbalised at the word-formation level by the propositional structure AKTOR - SITUATION/PRÄDIKAT (SITUATION) ZEIT/ACTOR - SITUATION/PREDICATE (SITUATION) - TIME. As a unit of knowledge representation, proposition is defined as a special mental structure, reflection of a situation and types of its inner relations generalised and structured in our consciousness (Pankrats, 1992). In this mental structure, ACTOR objectifies the idea of the active substance, PREDICATE (SITUATION) (atomic predicate) points to the most generalised and abstract type of connection, whereas the TIME argument captures the activity time of the subject's entity. The propositional structure ACTOR SITUATION/PREDICATE (SITUATION) - TIME verbalised by the composite words formed on the models $N+N, N+N(v), A+N$ with the general derivational meaning jmd., der irgendwann tut, lebt, aktiv ist/someone who does, lives, is active any time gives an idea about the activity, the life cycle of nature objects and objects of the reality, perceived by a man as a living being, the action producer.

The identification of a man with nature, the transfer of the properties inherent by nature to natural objects, as well as attributing to them the ability to appear in the human-like physical image in science, is associated with the features specific to mythological thinking.

The key component of a compound word can be either a substantive or a substantive name. According to the model presented, the following composite words are formed: Nachtschwester, die - Krankenschwester, die den Nachtdienst versieht (Duden, 1996, p. 1056), the example is translated into English as "night nurse - the nurse that provides the night shift"; Weihnachtsmann, der-Gestalt des heiligen Nikolaus oder Knecht Ruprecht, der nach altem Volksbrauch am Nikolaustag oder am Weihnachtsabend den Kindern Äpfel, Nüsse, Süßigkeiten oder kleine Geschenke bringt (Wahrig, 2001, p. 1384)/Santa Claus - Figure of St. Nicholas or Father Chrismas, who brings apples, nuts, sweets or small presents to children on St. Nicholas' Day or on Christmas Eve; Weihnachtskaktus, der - (um die Weihnachtszeit blühender) Gliederkaktus (Duden, 1996, p. 1724)/Christmas cactus - (blooming at the Christmas time) link cactus; Osterblume, die - im frühen Frühjahr blühende Pflanze unterschiedlicher Art (bes. Osterglocke, Buschwindröschen) (Duden, 1996, p. 1109)/Easter 
flower - in the early spring flowering plant of various kinds (especially daffodil, wood anemone); Sommerblume, die - im Sommer blühende Blume (Duden, 1996, p. 1416)/ summer flower-blooming flower in summer.

In the modern language, this propositional structure can model a subjective view of the activity of abstract and inanimate entities, to which a person attributes anthropomorphic properties. The "naive picture of the world" was created according to the anthropocentric canon that translates into the very possibility of thinking of natural phenomena or abstract concepts as "objectified", like faces or living beings with anthropomorphic, zoomorphic, and the like properties (Telia, 1988, p. 174). Cf.: Frühlingsregen, der - im Frühling fallender Regen (Duden, 1996, p. 544) / spring rain - rain falling in spring; Sonntagszeitung, die - an Sonntagen erscheinende Zeitung (Duden, 1996, p. 1420) / Sunday newspaper; Wochenzeitung, die - wöchentlich erscheinende Zeitschrift, Zeitung (Duden, 1996, pp. 1750-1751)/weekly magazine, newspaper; Jahrbuch, das - jährlich erscheinender Band mit Beiträgen zu einem bestimmten Fachgebiet (Duden, 1996, p. 785)/yearbook - annual volume with contributions to a specific field.

An important component of the TIME concept is the idea of its cyclicity, which is associated with the mythological consciousness by many scientists. The world process in the mythological consciousness used to be a series of repeated acts. The concept of the cyclical nature of time is interlinked with the perception of natural cycles: the changing of seasons, the time of day and recurring events in a human life.

The natural cycle determines some changes occurring in living beings and weather phenomena. This kind of knowledge is reflected in a number of units objectifying the characteristics of living objects according to the time of their activities. These can be formally divided into four groups: concerning the change of seasons of the year, months, changing times of day, the cycle of holidays.

In the change of seasons in German culture, special attention was paid to spring, the arrival of which, according to a man's ideas, symbolised the awakening of nature from a long sleep, and along with it, life. The expectation of this season, with which many hopes have been associated, is objectified in the composite word: die Frühlingssehnsucht/spring yearning. 
Nature was transforming, and new flowers could be seen in the fields and forests: der Frühlingskrokus/spring crocus, die Frühlingsknotenblume/spring snowflake, das Frühlingshungerblümchen/spring faverel, das Frühlingskreuzkraut/spring ragwort, der Frühlingswasserstern/spring water starwort.

At the same time, the superficial and deep semantic structure of these nominees may reveal a difference in the establishment of conceptual links. Thus, the plant das Sommertürchen (lat. Leucoium vernum) (Carl, 1995, p. 113)/summer snowflake that never used to blossom out before June, though having a tendency to appear in early spring, is attributed the anthropomorphic sign 'the ability to open the door into the summer' by the representatives of German culture.

The formation of the meaning of this structurally unmotivated complex word is based on the interaction of the mechanisms of conceptual metaphor and metonymy. From the source area MENSCH/MAN, the 'the ability to produce an action' (to open the door) is projected into the target area PFLANZE/PLANTS, alongside which the metaphorical understanding of time allows the conceptualisation of time (SOMMER/ SUMMER) as a closed space (RAUM/SPACE) that can be opened. Being built upon the mechanism of conceptual metonymy, which is centred on shifting the focus of attention from the actor to the object of the action, the conceptualisation of the AKTOR/ACTOR category is carried out. This explicitly establishes the relationship with the ZEIT/TIME category, and implicitly - with the HANDLUNG/ACTIVITY concept.

Knowledge of the time of crop ripening including winter crops, and of the need to harvest in time, is reflected in the derivatives Sommerweizen, Sommergerste, Sommerroggen, Sommerraps/summer wheat, spring barley, summer rye, summer rape; Winterweizen, Wintergerste, Winterroggen, Winterraps/winter wheat, winter barley, winter rye, winter rape.

The name of the autumn flower die Herbstzeitlose/autumn crocus in its conceptual structure reflecting a person's knowledge of its long blossom, the second designation is Michaelisblüte, due to the flowering time am Michaelistag/St. Michael's Day (September, 29 ${ }^{\text {th }}$ ) (Carl, 1995, p. 115): it is believed that autumn is considered to 'rightfully come into its own'. Metaphorical understanding of the seasons by the representatives of German culture allows us to attribute the characteristics of a living substance to time. 
Among the winter floral designations, such composite nouns as die Winteraster, das Wintergrün, Winterzwiebeln, der Winterkohl (Carl, 1995, p. 114)/winteraster, wintergreen, winter onions, winter cabbage should be mentioned.

While the temporal sign in the compound word representing PFLANZE/PLANT indicates the period of its flowering, in the composite noun objectifying WETTER/ WEATHER it is associated with the intensity of the development of an object's certain features: Sommerregen, der - meist leichterer Regen, wie er im Sommer fällt (Duden, 1996, p. 1417)/summer rain - usually lighter rain, as it falls in summer; Frühlingsluft, die - laue, linde Luft, wie sie der Frühling bringt (Duden, 1996, p. 544)/spring air - balmy, linden air, as spring brings; Herbstsonne, die - schwächer werdende Sonne im Herbst (Duden, 1996, p. 692)/autumn sun - dwindling sun in autumn; Herbstlaub, das - bunt gefärbtes Laub der Bäume im Herbst (Duden, 1996, p. 692)/autumn leaves - brightly coloured foliage of the trees in autumn; Winterwetter, das - kaltes Wetter, wie es im Winter herrscht (Duden, 1996, p. 1746)/winter weather - cold weather, as it prevails in winter. The emergence of such designations is determined by the sensory perception of human changes that occur in the outer world, and the selection of certain signs as the most typical and frequent.

The group of nominees, representing the idea of the cyclical nature of time as a change in the seasons of the year, is organically complemented by the composites reflecting knowledge of changes in wildlife during a 12-month annual cycle. Changes in the external characteristics of plants fix the designations die Märzblumen (der Löwenzahn, die Primel, das Buschwindröschen u.a.) (Carl, 1995, p. 112)/March flowers (dandelion, primrose, anemone, etc.), Maiblumen und Maikräuter (Schattenblume, Maiglöckchen, Waldmeister)/May flowers and May herbage (May lily, lily of the valley, woodruff), die Augustblume (Sandstrohblume)/August flower (yellow everlasting).

In May, birch (die Birke) gets covered with green foliage, so it was called der Maienbaum. At the end of the summer, hazel-tree bears the first fruits, which were named Augustnüsse (Carl, 1995, p. 112) by the time of their ripening.

The blossom-time is also marked by the designations of the plants, classified according to the cycle of church holidays. So, by Ostern/Easter, die Osterglocke (die Narzisse)/lent lily (daffodil) and die Osterblume (das Leberblümchen)/hepatica flourish, for die Pfingsten/the Trinity Day - die Pfingstrose (Paeonie)/peony, die Pfingstnelke and das 
Pfingstveilchen, while by the day of summer solstice (der Johannistag/St. John the Baptist's Day), by June $24^{\text {th }}$, die Johannisbeere/currant, das Johanniskraut/St. John's wort ripens, and for Christmas, Advents- oder Weihnachtsstern (Carl, 1995, pp. 114-115)/poinsettia blossoms out.

As the material analysed shows, a significant portion of the flora terms captures the communication participant's view concerning the change in the external appearance of the object associated with the blossom-time. In our opinion, the informative significance, which contributed to the verbalisation of knowledge about the flowering period, is due to the tradition of the German ethnos, i.e. to use beautifully shaped and brightly coloured plants with flowers for decorating rooms, gardens, parks, etc., and also as medicines.

As for animals, the time sign characterises the period of their coming-into-being or the period of their activity: Märzmücken (Märzfliegen)/March fly, der Maikäfer/ May-bug, der Maikärpfling (Killifisch)/Mayfish, bass killy, der Junikäfer/European June beetle. The semantic structure of derivatives nominee considers not only knowledge about the time of the appearance of offspring but also about the dangers that are associated with springtime weather: high water, severe frosts can easily destroy the March brood.

The characteristics of living beings' activity by day-time is objectified by the nominal derivatives die Tagraubvögel/diurnal birds of prey, der Nachtfalter (Carl, 1995, p. 110)/moth, der Nachtaffe (lat. Aotes) (Wahrig, 2001, p. 903)/night monkey, die Nachtigall (Germ. "galan» singen)/nightingale, der Abendsegler (Fledermaus, lat. Nyctalus noctula) (Carl, 1995, p. 111)/noctule bats.

The concepts of TAG and NACHT are the key constituents in the following composite words: die Taglilie (lat. Hemerocallis)/hosta, die Nachtkerze (lat. Oenothera)/ evening primrose - along with cyclicity, shade 'duration' can be singled out here.

In general, it should be noted that there are some discrepancies in the nominations of the wildlife in everyday speech and scientific discourse. Everyday consciousness is able to focus attention on these or those object's features of the reality, fixing this experience in separate language structures, and causing heteronomination. Scientific discourse, in its turn, is marked by terms or Latin designations. 
The concepts of temporal characteristics assigned to one or another representative of the living world do not coincide in terms of volume. In the ordinary consciousness, a person, as a rule, attributes time characteristics to all representatives of a certain kind of living beings. So, in German culture there is an idea that moths lead an active lifestyle only at dusk, objectified in the composite der Nachtfalter/moth.

In scientific discourse, the living creatures of one subspecies, on the contrary, can be interpreted as opposed to the time cycle features of the life cycle, cf.: der Tagfalter (Wahrig, 2001, p. 1233)/butterfly - der Nachtfalter (Wahrig, 2001, p. 903)/moth; das Sommergoldhähnchen (lat. Regulus ignicapillus) (Carl, 1995, p. 113)/firecrest - das Wintergoldhähnchen (lat. Regulus regulus) (Carl, 1995, p. 113)/goldcrest; die Sommerlinde (Tilia platyphyllos) (Carl, 1995, p. 113)/large-leaved linden - die Winterlinde (Tilia ulmifolia) (Carl, 1995, p. 113)/small-leaved linden.

While natural phenomena and flora and fauna species receive temporary characteristics taking into consideration their natural cycles, the category of nomination for human activity includes primarily acyclic situations that violate stereotypical ideas about the time of human activity/passivity.

Thus, there is a composite word das Siebenmonatskind - ein Kind, das sieben Monate nach der Empfängnis zur Welt gekommen ist (Sprach-Brockhaus, 1984, p. 633)/a seven-month baby - a baby born seven months after conception, but the compound word das Neunmonatskind/a nine-month baby does not exist in German.

The creation of the concept die Tagesmutter - Frau, die kleinere Kinder von vor allem berufstätigen Müttern tagsüber, meist zusammen mit ihren eigenen, in ihrer Wohnung gegen Bezahlung betreut (Duden, 1996, p. 1510)/the childminder - a woman who takes care of working mothers' smaller children during the day, usually together with their own, in their home for a fee - is due to the contradiction between the normative model of the mother and her role in the upbringing of children and the real state of affairs. In Germany, women nowadays working harder and more often, have to leave their children with a nanny, who takes over the mother's functions during the day.

Changes in the traditional understanding of a spouse's role as a life partner (der Lebensgefährte/the life companion) are evidenced by the emergence of the concept 
der Lebensabschnittsgefährte, der Lebensabschnittspartner in the German culture which actualises the modern idea of the fragility and temporal nature of the relationship between a man and a woman.

The designation die Wochenendehe - Ehe, bei der beide Partner (weil sie an verschiedenen Orten arbeiten) nur am Wochenende zusammenleben (Duden, 1996, p. 1750)/a weekend marriage - a marriage in which both partners (because they work in different places) live together only at weekends - actualises the idea of a modern marriage in which spouses often work in different cities and meet up only at weekends.

Compound nouns such as der Nachtmensch, das Nachttier: Nachtmensch, der jmd., der gerne bis spät in die Nacht aufbleibt, nachts aktiv wird; Nachttier, das nachtaktives Kind (Duden, 1996)/a night owl - someone who likes to stay up late into the night, gets active at night are obliged by their emergence to the idea that at night a person should rest, and not be awake.

In some cases, along with informative significance, such composite words represent a special communicative value, as they express the speaker's assessment of the perceived situation, cf.: Sonntagsfahrer, der (abwertend) - Autofahrer, der sein Auto nicht häufig benutzt und darum wenig Fahrpraxis hat (Duden, 1996, p. 1419)/Sunday driver (derogatory) - driver who does not use his car frequently and therefore has little driving experience; Sonntagsjäger, der (iron.) - jmd., der nur selten auf die Jagd geht, ungeübter, schlechter Jäger (Duden, 1996, p. 1419)/Sunday hunter (iron.) - someone, who rarely hunts, untrained, bad hunter; Sonntagsmaler, der - jmd., der die Malerei in seiner Freizeit, als Steckenpferd betreibt, ohne eine entsprechende Ausbildung zu besitzen (Duden, 1996)/Sunday painter - someone, who does the painting in his/her spare time, as a hobby without proper training to possess.

Modelling the idea of the period 'duration' of activity of subject entities can be based on the interaction of the AKTOR/ACTOR concept with those of DAUER/LONG, KURZ/SHORT: Dauerseller, der - Buch, das sich längere Zeit gut verkauft (Wahrig, 2001, p. 334)/Dauerseller - book that sells well for a long time; Kurzparker, der-jmd., der bis zu zwei Stunden parkt (Wahrig, 2001, p. 792)/short-term parker - someone who parks for up to two hours; Dauermagnet, der - Körper, der dauernd magnetisch bleibt, der nach Magnetisierung in einem Magnetfeld auch bei ausgeschaltetem äußerem Feld 
magnetische Kräfte ausübt (Wahrig, 2001, p. 334)/permanent magnet - body that remains permanently magnetic, which, after magnetization in a magnetic field, exerts magnetic forces even when the external field is switched off.

\section{Conclusion}

Summing up all stated above, we conclude the following.

1. The results of a man's comprehension of time are reflected in the language time model. Thus, the mental structure AKTOR - SITUATION/PRÄDIKAT (SITUATION) - ZEIT/ ACTOR - SITUATION/PREDICATE (SITUATION) - TIME, verbalised by composite words of the modern German language, and formed on the models $N+N, N+N(v), A+N$, shapes the idea of the wild life objects' activity and life cycle, as well as those of abstract and inanimate entities, to which a person attributes anthropomorphic properties.

2. The propositional structure AKTOR - SITUATION/PRÄDIKAT (SITUATION) - ZEIT/ ACTOR - SITUATION/PREDICATE (SITUATION) - TIME objectifies the person's subjective view of life cycles, activity/passivity of living beings. Thus, within the scope of nomination in question, we distinguish two groups of notions, i.e., first and foremost, temporal peculiarities of living creatures that characterise their ontological essence, and secondly, acyclic situations that destroy traditional ideas about the activity time and human activity, which testify to the informative value of these fragments of reality for representatives of the German ethnic group.

Grant Support: The author received no financial support for this work.

\section{References}

Arutyunova, N.D. (1999). Language and Human World. Moscow: Languages of Russian Culture.

Carl, H. (1995). German Plant and Animal Names. Heidelberg, Wiesbaden: Quelle\&Meyer.

Der Sprach-Brockhaus (1984). German Picture Dictionary from A to Z. Wiesbaden: Brockhaus.

Duden (1996). Duden German Universal Dictionary. Mannheim: Dudenverlag.

Kant, I. (1966). Works in 6 Volumes / in V.F. Asmus, A.V. Guliga, T.I. Oizerman (eds.). Series Philosophical Heritage.

Retrieved from https://platona.net/load/knigi_po_filosofii/istorija_nemeckaja_klassicheskaja/kant_ immanuil_sochinenija_v_6_tomakh/12-1-0-1481 
Kravchenko, A.V. (2004). Language and Perception: Cognitive Aspects of Language Categorization (2nd ed.). Irkutsk: Irkutsk State University Publishing House.

Kubryakova, E.S. (2004). Language and Knowledge. Moscow: Languages of Slavic Culture.

Newton, I. (1687). Mathematical Principles of Nature Sciences. Retrieved from URL: https://de.wikipedia.org/wiki/ Zeit

Pankrats, Yu.G. (1992). Propositional Form of Knowledge Representation. Language and Structures of Knowledge Representation. Moscow: INION Publishing House.

Teliya, V.N. (1988). Metaphorization and its Role in the Creation of a Language Picture of the World. The Role of Human Factor in Language: Language and World View. Moscow: Science.

Voronina, L., Skokova, T., Melnikova, Y., Yarygina, O., \& Miroshnichenko, G. (2018). The Role of Language Representation of the Time Model in the Process of Meaning Creation. Journal of History Culture and Art Research, 7(2), 94-100.

doi:http://dx.doi.org/10.7596/taksad.v7i2.1586

Wahrig, G. (2001). German dictionary. Gütersloh, München: Bertelsmann Lexikon Verlag. 